\title{
Medium and large mammals in a Cerrado fragment in Southeast Goiás, Brazil: inventory and immediate effects of habitat reduction on species richness and composition
}

\author{
Ednaldo Cândido Rocha ${ }^{1,2 *}{ }^{\circledR}$, Jhefferson Silva ${ }^{2}$, Pablo Timóteo da Silva ${ }^{1}$, Márcio da Silva Araújo $^{I}$ \& André \\ Luis da Silva Castro ${ }^{2}$ \\ ${ }^{1}$ Universidade Estadual de Goiás, Campus de Ipameri, Rodovia GO 330, km 241, Anel Viário, 75780-000, \\ Ipameri, GO, Brasil. \\ ${ }^{2}$ Instituto Federal Goiano, Programa de Pós-Graduação em Conservação de Recursos do Cerrado Natural, \\ Campus Urutai, Urutai, GO, Brasil \\ *Corresponding author: Ednaldo Cândido Rocha, e-mail: ednaldo.rocha@ueg.br
}

ROCHA, E.C., SILVA, J., SILVA, P.T., ARAÚJO, M.S., CASTRO, A.L.S. Medium and large mammals in a Cerrado fragment in Southeast Goiás, Brazil: inventory and immediate effects of habitat reduction on species richness and composition. Biota Neotropica. 19(3): e20180671. http://dx.doi.org/10.1590/1676-0611BN-2018-0671

\begin{abstract}
The reduction and fragmentation of remnant vegetation habitats has been one of the main threats to Cerrado biodiversity. The aim of the present study is to make an inventory of medium and large mammal species in a Cerrado remnant and to assess deforestation influence on part of this fragment on the richness and composition of mammal species. The study was conducted in a Cerrado fragment in southeast Goias State, Ipameri County. Data were collected during three different periods (P1, January-June, 2014; P2, December, 2016 - June, 2017; P3, July-December, 2017) through direct (visual, vocal and camera-trap records) and indirect methods (foot prints, animal burrows and other traces) in order to register the mammal species. Jackknife 1 estimator was used to estimate species richness during each of the three sampled periods and for the complete collection period; species similarity between periods was assessed through the Jaccard's Index of Similarity (Cj). Species richness between periods was performed through inference by overlapping confidence intervals (CI). Twenty-nine species were recorded during the assessed period, five of them were listed as endangered in Brazil. There was no significant change in species richness between the assessed periods: species richness of 25 species was observed in Period 1 (P1), the richness of 32 species was estimated $(\mathrm{CI}=4.58) ; 23$ species were recorded in Period $2(\mathrm{P} 2)$, and the richness of 30 species was estimated $(\mathrm{CI}=4.39)$, the richness of 23 species was observed in Period $3(\mathrm{P} 3)$ and the richness of 28 species was estimated $(\mathrm{CI}=4.70)$. Similarity in species composition between the assessed periods recorded $\mathrm{Cj}=$ $0.71(71 \%)$ between $\mathrm{P} 1$ and $\mathrm{P} 2, \mathrm{Cj}=0.66(66 \%)$ between $\mathrm{P} 1$ and $\mathrm{P} 3$, and $\mathrm{Cj}=0.77$ between $\mathrm{P} 2$ and $\mathrm{P} 3$. Fragment deforestation did not influence the richness and composition of medium and large mammal species (within a period of 2 3 years) when the three periods were compared; however, the absence of changes in the community can be the result of time-lag, therefore, we cannot put aside the likelihood of mid and long-term effects.
\end{abstract}

Keywords: mammal fauna; wildlife survey; species composition; fragmentation.

\section{Mamíferos de médio e grande porte em um fragmento de Cerrado, no sudeste de Goiás, Brasil: inventário e efeitos imediatos da redução de habitat na riqueza e composição de espécies}

\footnotetext{
Resumo: A fragmentação e a redução de hábitat de vegetação remanescente tem sido as principais ameaças à biodiversidade do Cerrado. Este trabalho teve como objetivo inventariar as espécies de mamíferos de médio e grande porte em um fragmento de Cerrado e avaliar a influência do desmatamento de parte desse fragmento na riqueza e composição de espécies de mamíferos. O estudo foi conduzido em um fragmento de Cerrado, no sudeste do Estado de Goiás, município de Ipameri. Os dados foram coletados em três períodos (P1 - janeiro-junho/2014, P2 - dezembro/2016-junho/2017 e P3 - julho-dezembro/2017) utilizando métodos diretos (visual, vocal e registros fotográficos) e indiretos (pegadas, tocas e outros sinais) para o registro das espécies de mamíferos. Foi estimada
} 
a riqueza de espécies para os três períodos amostrados e para todo período utilizando o estimador Jackknife 1 e a semelhança de espécies entre os períodos, pelo Índice de Similaridade de Jaccard (Cj). A comparação da riqueza de espécies estimada entre os períodos foi realizada pela inferência por sobreposição dos intervalos de confiança (IC). Em todo o período estudado foram registradas 29 espécies, sendo 5 destas listadas como ameaçadas de extinção no Brasil. Entre os períodos amostrados não foi observada mudança significativa na riqueza de espécies, sendo que no período 1 (P1) foi observada a riqueza de 25 espécies e estimada de 32 (IC = 4,58), no período 2 (P2) registrou-se 23 espécies e estimou-se $30(\mathrm{IC}=4,39)$ e no período $3(\mathrm{P} 3)$ a riqueza observada foi de 23 espécies e estimada 28 ( $\mathrm{IC}=4,70)$. A similaridade na composição de espécies entre os períodos foi de $\mathrm{Cj}=0,71(71 \%)$ entre $\mathrm{P} 1$ e P2, Cj = 0,66 (66\%) entre P1 e P3 e Cj=0,77 entre P2 e P3. Não foi observada influência do desmatamento do fragmento (no período de 2 a 3 anos) na riqueza e composição de espécies de mamíferos de médio e grande porte, comparando os três períodos amostrados. Contudo, a ausência de alterações na comunidade pode ser decorrente de um time-lag, não podendo descartar possíveis efeitos a médio e longo prazo.

Palavras-chave: mastofauna, levantamento de fauna, fragmentação, perda de habitat.

\section{Introduction}

Habitat fragmentation and loss processes have been seen as the main threats to biodiversity (Ahumada et al. 2011, Gibson et al. 2011). These processes change the disposition and habitat connectivity, but they are different. The fragmentation turns areas into smaller remnants at different isolation levels, whereas the habitat loss does not necessarily cause any disruption in fragment continuity (Fahrig 2003).

It is possible to observe changes in the landscape and in connectivity, as well as increase in the matrix area and in the border effect, after fragmentation (Uezu et al. 2005, Michalski \& Peres 2007, Norris et al. 2008). These changes can lead to alterations in local biodiversity, either at population level - such as changes in abundance, reproduction; in the distribution, recruiting and survival rates of individuals (Wolff et al. 1997, Fahrig 2003) - or at community level, as well as changes in species richness and composition (Chiarello 1999, Santos-Filho et al. 2012).

Habitat reduction and fragmentation can cause many losses to the fauna, such as reduction in shelter, food availability and in the availability of reproduction locations. Moreover, this reduction can increase or reduce fauna flow depending on the affected species, fact that exposes these species to predators and hunters (Cullen Jr. et al. 2000, Peres 2000). One additional effect of habitat reduction or fragmentation is population isolation, that is responsible for gene flow reduction, which, consequently, leads to reduction in local fauna population and even to the extinction of some species in the region (Fahrig 2003). The ability of some species to remain in fragmented sites is related to their biological characteristics, such as body size (Rocha et al. 2018), area for use, population density, specificity of habitat use, reproduction rate (Arita et al. 1990, Cardillo \& Bromham 2001, O'Grady et al. 2004) and their ability to cross large unfavorable areas (Dale et al. 1994).

The Cerrado biome covers approximately $23 \%$ of the national territory and it was included among the 34 hotspots in the planet due its high biodiversity, degree of endemism and endangerment (Mittermeier et al. 2005). Cerrado has been facing the fast reduction of its original vegetal cover in the last five decades given the expansion of agricultural frontiers in Central Brazil. Therefore, this biome is currently highly fragmented in many regions (Sano et al. 2007, Carvalho et al. 2009, Strassburg et al. 2017).

Cerrado houses at least 251 mammal species; 32 of them are endemic and 16 are listed as endangered in Brazil (Paglia et al.
2012, MMA 2014). The mammals has been considered as one of the biologic groups mostly influenced by habitat fragmentation, due to the characteristics of their species, since most of them need large areas to live (at certain preservation degree), have higher demands for resources in order to survive and present low reproduction rates (Cardillo et al. 2005).

Studies about Cerrado assessing the effects of fragmentation on wild mammals remain scarce; thus, the aim of this study was to survey medium and large mammal species in a Cerrado fragment in Southeast Goias State and to assess deforestation influence on the richness and composition of mammal species.

\section{Material and Methods}

\section{Study site}

The study was conducted in a Cerrado fragment (coordinates: $17^{\circ} 40^{\prime} 31^{\prime \prime} \mathrm{S} ; 48^{\circ} 05^{\prime} 09^{\prime}$ ' W) in southeast Goias State, Ipameri County (Figure 1). The private property where the research was conducted holds Cerrado remnants that exceed the minimal requirements for rural real estate (Brasil, 2012). However, part of this native vegetation was legally removed between 2014 and 2017, with emphasis to soil use for agricultural purposes.

Part of the natural vegetation in the fragment where the study was conducted was suppressed. Before the beginning of vegetation suppression, in 2014, the fragment has an area of 284 ha; between December 2016 and July 2017, the area was reduced to 204 ha, thus it lost $28 \%$ of its native vegetation cover; and from July to December 2017 the area was reduced to 196 ha, $30.9 \%$ loss in relation to 2014 (Figure 1).

\section{Sampling}

Data were collected between 2014 and 2017 during three different periods: January-July, 2014 (P1) [sample effort (n)=4 days], December, 2016 - June, 2017 (P2) [n=6 days] and July-December, 2017 (P3) $[\mathrm{n}=6$ days $]$.

Active searches were performed, totaling 64 hours, and the species were recorded through direct (visual and vocal) and indirect methods (foot prints, animal burrows and other traces) (Rocha et al. 2015). In addition, two camera traps (Bushnell, digital - 8 mega pixel resolution) were used between December 17, 2016 and December 28, 2017, when 


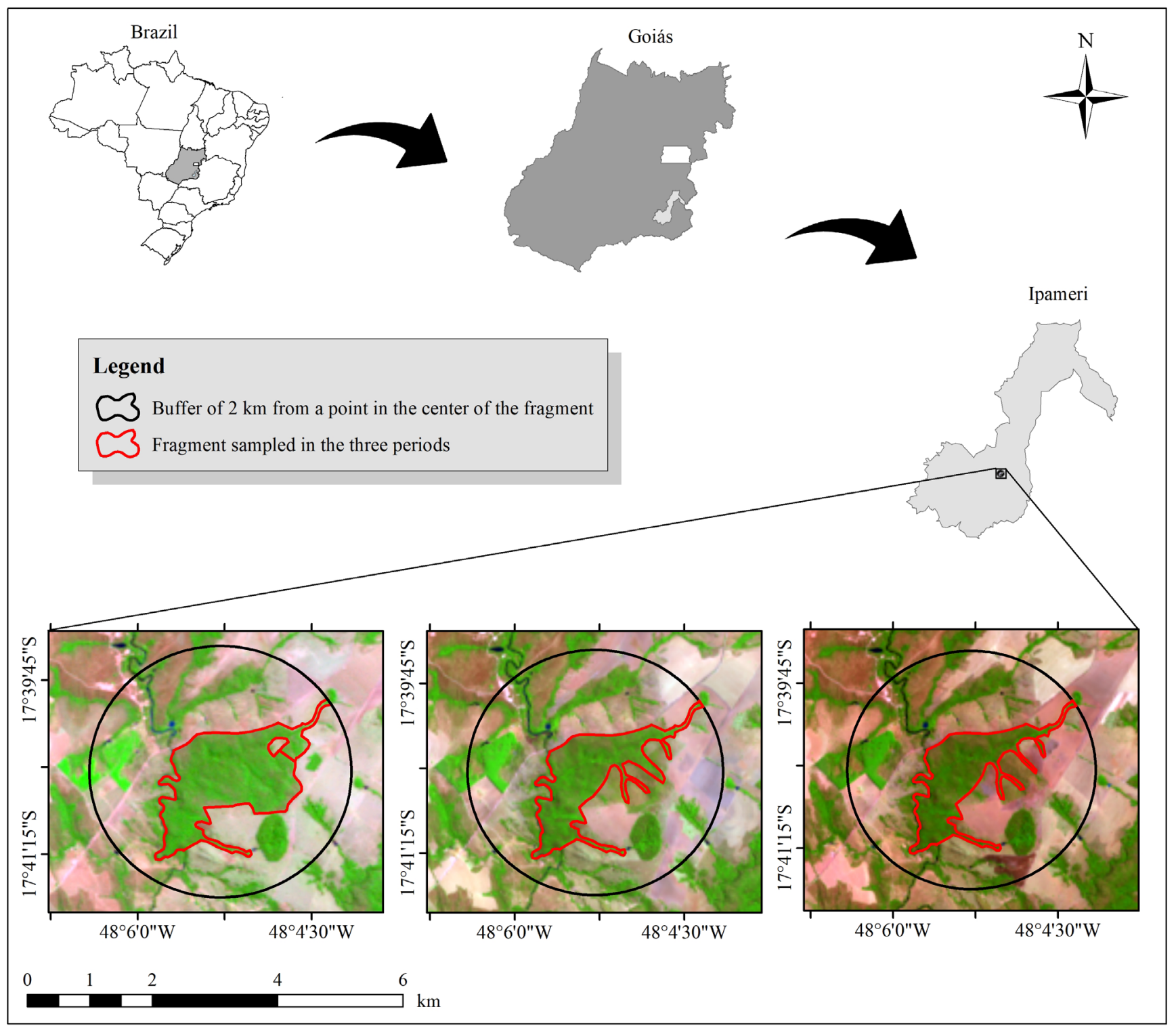

Figure 1. Location of the sampled fragment and fragment situation in each period [Period 1 (P1): January, 2014 - 284ha; Period 2 (P2): December, 2016 June, 2017 - 204ha; and Period 3: July-December, 2017 - 196ha], Ipameri County, southeast Goias state.

these traps were removed from, or reinstalled in, different spots, without baits, in locations likely crossed by the local fauna. This method totaled 376 traps-night sampling effort.

The active searches were performed in roads, tracks, banks of water courses and in their surroundings. The study site was randomly crossed in search for evidences of medium and large mammals. When any animal was visualized or when any evidence of mammals was found, they were identified (Becker \& Dalponte 2013) and recorded in a field book along with information about the location and type of sampled environment. In this study, the taxonomic arrangement followed Paglia et al. (2012).

\section{Data analysis}

The landscape in a $2 \mathrm{~km}$ radius was measured from a spot in the center of the assessed fragment to quantify the habitat extension within the fragment. Two classes of landscape classification were adopted: 1)
Habitat - Forest and/or denser Cerrado areas; 2) non-habitat - areas with altered original vegetation, fields, lakes and rivers (Rocha et al. 2018).

Species accumulation curves were generated from records of each mammal species collected in the study site through each of the used sampling methods (active search and camera trap), based on the rarefaction method (Gotelli \& Colwell 2011). Moreover, species richness in each sampled period was estimated in the Jackknife 1 estimator. The comparison of estimated species richness between periods was performed through inferences by confidence intervals. Thus, confidence interval overlap between a period and the mean richness of other period indicated similar species richness (Coelho et al. 2014). Species similarity among the three periods was measured through the Jaccard's Index of Similarity $(\mathrm{Cj})$, which was adopted to generate a dendrogram through the unweighted pair group method with arithmetic averages (UPGMA). 
The statistical analyses were conducted in the R Software (R Core Team 2018) - vegan package (Oksanen et al. 2018). Only data collected through active search were used to compare the assessed periods in order to standardize the methods used between periods, since Period 1did not use camera traps.

\section{Results}

\section{Species inventory}

Twenty-nine medium and large mammal species were recorded (table 1 and Figure 2) during the research. These species were divided in 8 orders: Carnivora (11 species), Cingulata (5 species), Primates (3 species), Cetartiodactyla (3 species), Didelphimorphia ( 2 species), Pilosa (2 species), Rodentia (2 species) and Lagomorpha (1 species). Five of the recorded species were classified as endangered in Brazil (MMA, 2014): Giant anteater (Myrmecophaga tridactyla), Giant armadillo (Priodontes maximus), Cougar (Puma concolor ), Maned wolf (Chrysocyon brachyurus) and Hoary fox (Lycalopex vetulus).
Species accumulation curves for this study not showed stabilization complete trend either in the active search or in the camera traps. This outcome indicates that the sampling effort, although good for small areas, not was enough to represent all species of the mammal fauna in the study site (Figure 3). Therefore, an increase in the sampling effort is expected to reveal some species not recorded in this study.

\section{Effects of habit loss on species richness and composition}

The assessed fragment covered 284ha before de deforestation period, which corresponds to Period 1 (P1); the landscape it was inserted in had 486ha. It presented the observed richness of 25 species and the estimated richness of 32 ones (confidence interval $-\mathrm{CI}=4.58$ ). Period 2 (P2) showed that the fragment had its territory reduced to 204 ha, $28 \%$ loss of its size and the habitat in the landscape recorded $16.5 \%$ reduction, it dropped to $406 \mathrm{ha}-23$ species and 30 estimates (CI=4.39). Period 3 (P3) recorded fragment area 196ha and the habitat in the landscape dropped down to 398ha, 23 species and 28 estimates (CI-4.70) (Table 2). The loss in fragment area reached 30.9\%, whereas the habitat loss in the landscape within a $2 \mathrm{~km}$ radius recorded $18.1 \%$.

Table 1. Medium and large mammal species recorded in a Cerrado fragment, Ipameri County - GO, during three periods: P1 = Jan-Ju1/2014, P2 = Dec/2016-Jun/2017 and P3 = Jul-Dec/2017. Type of record: $\mathrm{F}=$ foot print, $\mathrm{Vi}=$ visual, $\mathrm{Vo}=$ vocal, $\mathrm{B}=$ burrow, $\mathrm{Ca}=$ carcass and $\mathrm{Ct}=$ camera trap. * endangered species $(\mathrm{MMA}, 2014)$.

\begin{tabular}{|c|c|c|c|c|}
\hline Taxon & Common name & P1 & $\mathbf{P 2}$ & $\mathbf{P 3}$ \\
\hline \multicolumn{5}{|l|}{ Didelphimorphia } \\
\hline \multicolumn{5}{|l|}{ Didelphidae } \\
\hline Chironectes minimus (Zimmermann, 1780) & Water Opossum & $\mathrm{F}$ & & \\
\hline \multicolumn{5}{|l|}{ Pilosa } \\
\hline Tamandua tetradactyla (Linnaeus, 1758) & Southern Tamandua & $\mathrm{F}$ & $\mathrm{F}$ & $\mathrm{F}, \mathrm{Ct}$ \\
\hline Myrmecophaga tridactyla Linnaeus, 1758* & Giant anteater & $\mathrm{F}$ & $\mathrm{F}, \mathrm{Ct}$ & $\mathrm{F}, \mathrm{Ct}$ \\
\hline \multicolumn{5}{|l|}{ Cingulata } \\
\hline \multicolumn{5}{|l|}{ Dasypodidae } \\
\hline Cabassous unicinctus (Linnaeus, 1758) & Southern Naked-tailed Armadillo & B & & \\
\hline Priodontes maximus (Kerr, 1792)* & Giant Armadillo & $\mathrm{F}, \mathrm{B}$ & $\mathrm{F}, \mathrm{B}, \mathrm{Ct}$ & $\mathrm{F}, \mathrm{B}$ \\
\hline \multicolumn{5}{|l|}{ Cetartiodactyla } \\
\hline \multicolumn{5}{|l|}{ Cervidae } \\
\hline Mazama gouazoubira (G. Fischer, 1814) & South American Brow Brocket & $\mathrm{F}, \mathrm{Vi}$ & $\mathrm{F}, \mathrm{Ct}$ & $\mathrm{F}, \mathrm{Vi}, \mathrm{Ct}$ \\
\hline Mazama americana (Erxleben, 1777) & South American Red Brocket & $\mathrm{F}$ & $\mathrm{F}$ & $\mathrm{F}$ \\
\hline \multicolumn{5}{|l|}{ Tayassuidae } \\
\hline Pecari tajacu (Linnaeus, 1758) & Collared Peccary & $\mathrm{F}$ & $\mathrm{F}, \mathrm{Vo}, \mathrm{Ct}$ & $\mathrm{F}, \mathrm{Ct}$ \\
\hline \multicolumn{5}{|l|}{ Primates } \\
\hline
\end{tabular}


Continuation Table 1.

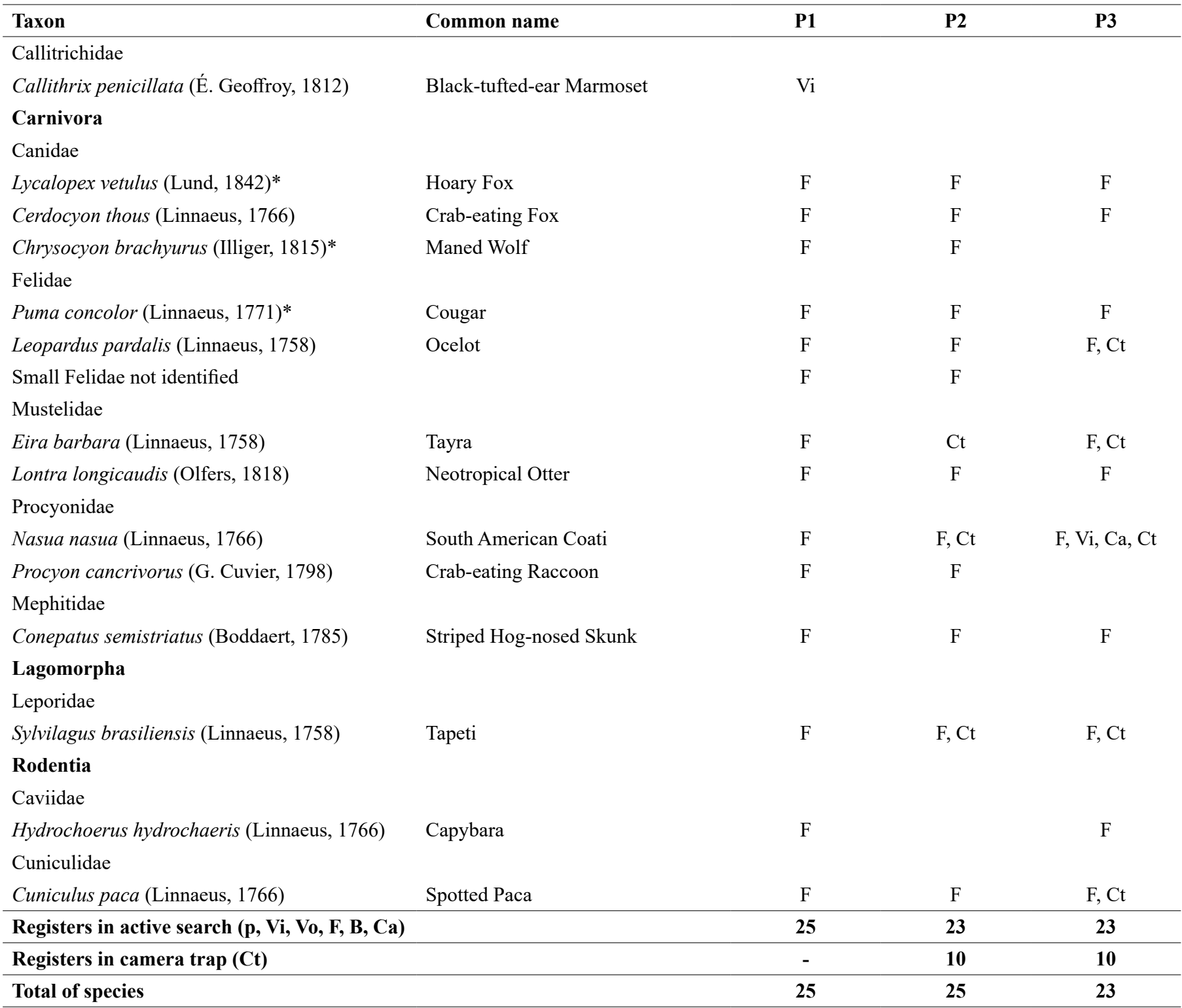

There was no statistically significant differences of mammal species richness between the sampled periods. Values resulting from the observed richness in the three periods were very close, besides the considerable overlap between confidence intervals and estimated richness (Table 2).

Species similarity between periods 1 and 2 was $C j=0.71$ - these periods shared 20 species. Periods 1 and 3 were similar, $\mathrm{Cj}=0.66-$ they shared 19 species; periods 2 and 3 were similar, $\mathrm{Cj}=0.77$ - they shared 20 species (Figure 4).

\section{Discussion}

The richness of mammal species observed during the entire study ( 29 species) can be classified as high, given the fact that the sampled fragment was relatively small. This outcome evidences the importance of Legal Reservation and Permanent Preservation areas, as the fragment sampled in the present study, for the conservation in situ of Cerrado mammal fauna, especially for endangered species. Estrela et al. (2015) conducted a comparative study in a mosaic composed of Cerrado fragments ( $512 \mathrm{ha}$ ) located approximately $25 \mathrm{~km}$ from the herein sampled fragment and recorded 25 mammal species. Rocha et al. (2015) studied a 618 ha fragment located approximately $95 \mathrm{~km}$ from our study site and recorded 23 medium and large mammal species. Their outcomes confirm the high richness of mammal fauna in the Cerrado biome in southeast Goias state.

The order Carnivora recorded the highest observed richness, 11 species, which corresponds to $37.9 \%$ of the species recorded in the site. This result is close to that recorded by other authors Bocchiglieri et al. (2010) in the Cerrado biome and by Hannibal (2014), in the Atlant forest biome. This order was followed by Cingulate, which presented 5 species $-17.2 \%$ of the species found. Individuals belonging to order Carnivora are often distributed in fragmented landscapes and most 
Rocha, E.C. et al.
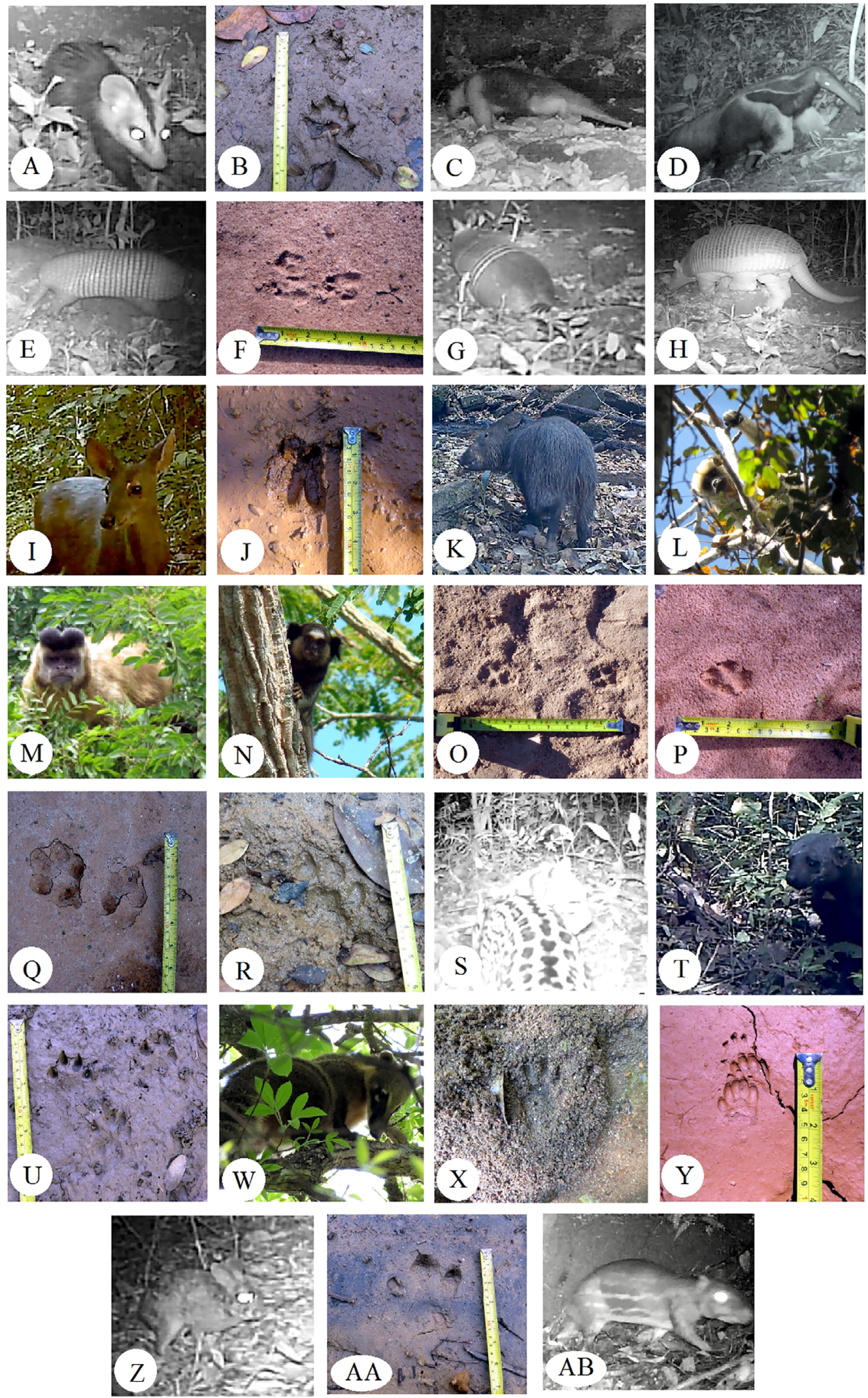

Figure 2. Recorders of medium and large mammal species in a Cerrado fragment in Southeast Goias State between 2014 and 2017: $\mathbf{A}=$ Didelphis albiventris, $\mathbf{B}=$ Chironectes minimus, $\mathbf{C}=$ Tamandua tetradactyla, $\mathbf{D}=$ Myrmecophaga tridactyla, $\mathbf{E}=$ Cabassous tatouay, $\mathbf{F}=$ Euphractus sexcinctus, $\mathbf{G}=$ Dasypus novemcinctus, $\mathbf{H}=$ Priodontes maximus, $\mathbf{I}=$ Mazama gouazoubira, $\mathbf{J}=$ Mazama americana, $\mathbf{K}=$ Pecari tajacu, $\mathbf{L}=$ Alouatta caraya, $\mathbf{M}=$ Sapajus libidinosus, $\mathbf{N}=$ Callithrix penicillata, $\mathbf{O}=$ Lycalopex vetulus, $\mathbf{P}=$ Cerdocyon thous, $\mathbf{Q}=$ Chrysocyon brachyurus, $\mathbf{R}=$ Puma concolor, $\mathbf{S}=$ Leopardus pardalis, $\mathbf{T}=$ Eira barbara, $\mathbf{U}=$ Lontra longicaudis, $\mathbf{W}=$ Nasua nasua, $\mathbf{X}=$ Procyon cancrivorus, $\mathbf{Y}=$ Conepatus semistriatus, $\mathbf{Z}=$ Sylvilagus brasiliensis, $\mathbf{A A}=$ Hydrochoerus hydrochaeris, $\mathbf{A B}=$ Cuniculus paca . 
Active search

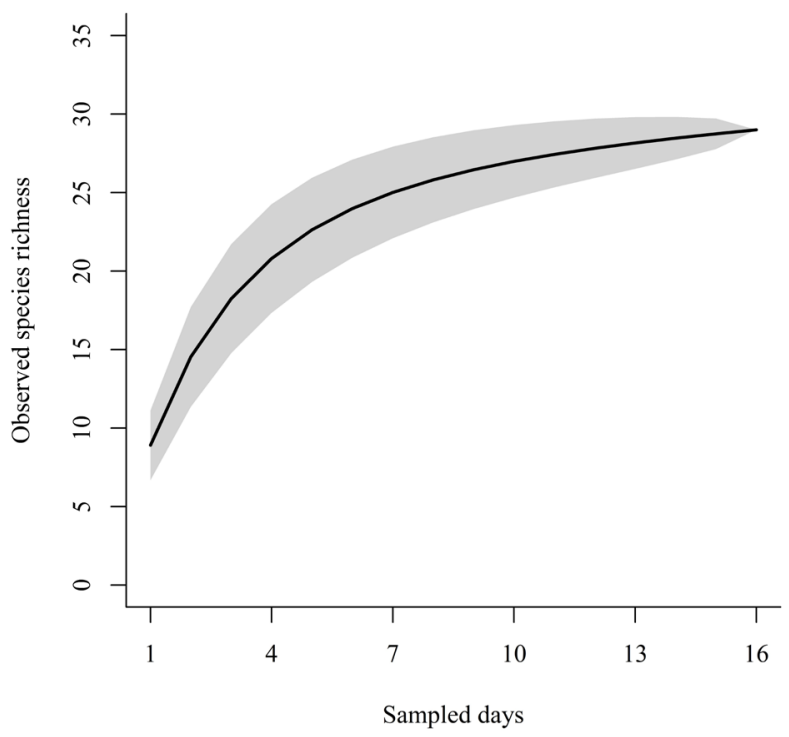

Camera trap

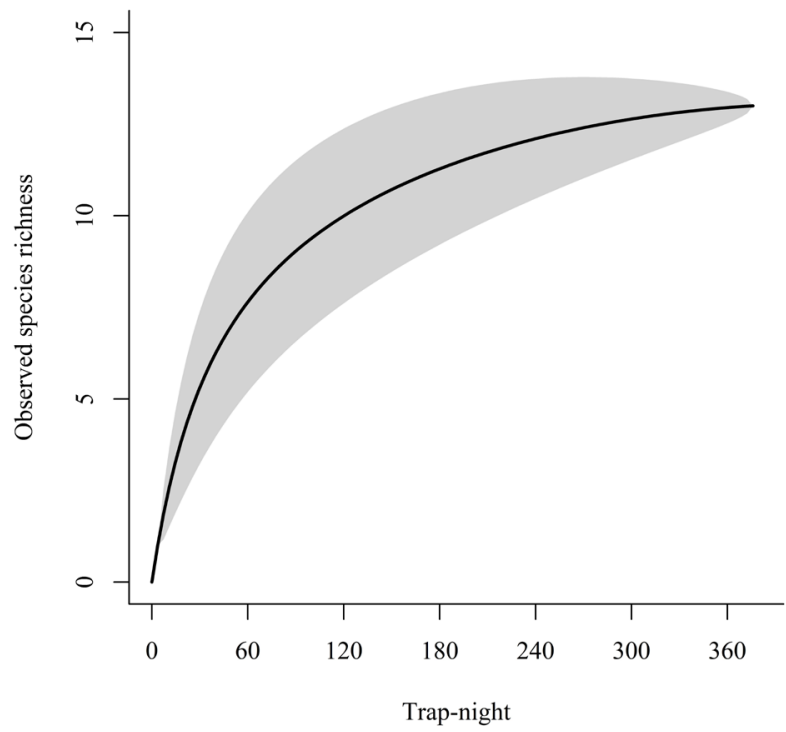

Figure 3. Rarefaction curves of the richness of medium and large mammal species recorded through active search and camera traps in a Cerrado fragment, southeast Goias, Ipameri County - GP, between 2014 and 2017.

Table 2. Fragment size (FS), fragment reduction (FR\%), amount of habitat in the landscape within a $2 \mathrm{~km}$ radius from the center of the fragment (AH), habitat reduction in the landscape (HRL\%), observed species richness (OR), estimated species richness (ER) and confidence interval (CI).

\begin{tabular}{|c|c|c|c|c|c|c|}
\hline Periods & FS (ha) & FR\% & AH (ha) & HRL\% & OR & ER (CI) \\
\hline P1 (Jan-Jun/2014) & 284 & - & 486 & - & 25 & $32(4.58)$ \\
\hline P2 (Dec/2016-Jun/2017) & 204 & 28.16 & 406 & 16.5 & 25 & $30(4.39)$ \\
\hline
\end{tabular}

Cluster analysis - UPGMA

(cophenetic correlation coefficient $=0.86$ )

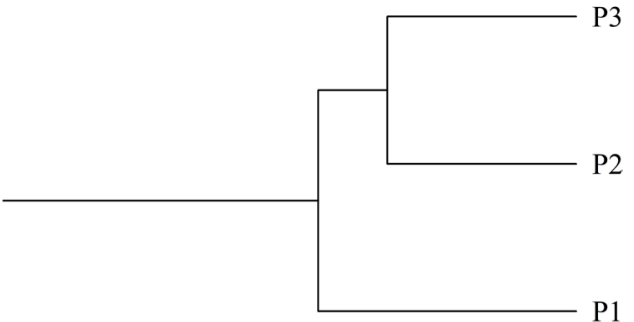

\begin{tabular}{|c|c|c|c|c|}
\hline & T & $T$ & $T$ & $T$ \\
\hline 0 & 0.2 & 0.4 & 0.6 & 0.8 \\
\hline
\end{tabular}

Figure 4. Dendrogram of the UPGMA based on the species similarity index among the three sampled periods (P1 = Jan-Jul/2014, P2 = Dec/2016-Jun/2017 and P3 = Jul-Dec/2017) in a Cerrado fragment in Ipameri County, southeast Goias state. species have great mobility and the ability to explore anthropized areas (Lyra-Jorge et al. 2008), a fact that might explain the high richness of these orders in the assessed fragment.

The present results do not evidence significant differences in species observed richness before and after vegetation suppression, since the time interval after habitat change was short (2-3 years) for the occurrence of radical changes in species richness. Zimbres et al. (2013) analyzed five species of Xenarthra in Cerrado and they did not find any differences of activity pattern between more or less fragmented areas. However, there was positive relation between mammal species richness and the size of forest fragments; such outcomes have already been shown in studies conducted with big-sized mammals in Atlantic Forest areas in Espirito Santo State (Chiarello 1999) and in the Brazilian southern Amazon (Michalski \& Peres 2007, Santos-Filho et al. 2012).

Some short-term changes in biodiversity can be observed after alterations in landscape, but some species have their population reduced, or even vanished, after a long period of time (Kuussaari et al. 2009). Species in a community need time (relaxation time) to adapt to new conditions after structural changes in the landscape and to regain balance (Kuussaari et al. 2009). This process can lead to two scenarios: first, the extinction debit, which happens when the limit condition for 
species survival after habitat loss is not reached. However, these species did not disappear yet due to their delayed response to environmental changes, but they will disappear with time (Tilman 1994, Jackson \& Sax 2009). Second, immigration credit, which increases the number of local species because the environment becomes appropriate for the occupation of new species. As long as the extinction debit and the immigration credit are over, the community returns to balance and biodiversity is finally restored (Jackson \& Sax 2009). According to Kuussaari et al. (2009), studies assessing the time interval between habitat changes and species responses open room for three hypothesis concerning factors that determine the likelihood and intensity of an extinction debit: (1) extinction debits must change depending on the biological characteristics of the affected species; (2) the intensity of an extinction debit must present non-linear relation to the intensity of habitat changes; e (3) extinction debits should decrease over time after habitat modification.

The number of species found in a fragment is linked either to habitat size or to the amount of habitat in the landscape; the richness of a fragment must increase according to the total amount of habitat in the local landscape (Fahrig 2013). On the other hand, as the habitat loss progresses, species richness in a certain type of habitat in the total landscape will diminish along with the total remnant area of the type of landscape, regardless of the individual size of the remaining fragments (Fahrig 2013).

Although there were no significant changes in species richness in the sampled periods, it is likely that such changes will happen in the long-term, since the extinction debits are much more likely to happen in landscapes that face intermediate habitat loss $(\sim 20-30 \%)$ than in landscapes that lose little or many habitats (Lira et al. 2012). Our results showed $30.9 \%$ fragment area loss and $18.1 \%$ landscape loss - extinction debit was expected. According to Hanski \& Ovaskainen (2002), yet, many species can persist for a long time close to the minimum habitat quality conditions necessary for population maintenance and to the extinction limits in landscapes where the habitat loss was intermediate. On the other hand, many species can persist for a long period in little habitat loss landscapes without facing strong adverse impact. Extinctions are expected to happen fast in landscapes facing very intense habitat loss (Lira et al. 2012).

Hunting is another important factor to be taken into account as it can influence the extinction of local mammal species, mainly of big-sized ones. This same pattern was detected and highlighted as relevant in other studies (Cullen Jr. et al. 2000, Peres 2000), because populations living in smaller fragments tend to be more vulnerable to predation and to be hunted by humans. Although hunting by humans was not observed in the assessed fragment, there were domestic dogs often hunting in the area, which can promote attacks on wild animals (Mendes et al. 2005, Silva \& Henrique, 2009).

Species compositions was similar between the sampled periods (Figure 4), but it did not show evidence drastic changes due to habitat reduction. The small difference in similarity mainly happened due to the occasional record of some species that were observed only in one field survey, such Water Opossum (Chironectes minimus), Southern Naked-tailed Armadillo (Cabassous unicinctus), Greater Naked-tailed
Armadillo (Cabassous tatouay), Black-tufted-ear Marmoset (Callithrix penicillata) and other species that were recorded in some periods and not recorded in others - even if the environment in the non- recorded periods favored the presence of such species.

Great changes in the richness and composition of medium and large mammal species were not observed in the assessed fragment during the sampled periods. According to Metzger et al. (2009), some species can be sensitive to changes in part of the landscape rather than to changes in the internal conditions or in areas of the fragment they occupy. Moreover, species presenting more ability to use habitats inserted in a matrix and to displace between fragments, such as medium and large mammals, can move and occupy different environments in a matrix. Consequently, they can be less affected by habitat fragmentation processes (Umetsu et al. 2008).

Semper-Pascual et al. (2018) observed that relaxation time (the time needed for a certain community to reach balance after landscape change) for birds and mammals in the Chaco Seco Argentino was 10 to 25 years. We cannot highlight the possible mid and long-term effects on mammal species, since we did not find deforestation effects on the richness and composition of these species in the short-term (2 3 years). Therefore, the absence of changes in the community can derive from time-lag. These changes in composition of mammals species should occur in a time greater than the duration of this study.

\section{Acknowledgments}

We thank the individuals and institutions that have directly or indirectly contributed to the conduction of this study, mainly to State University of Goias (UEG) for granting the scholarships to ECR and MSA(PROBIP/PrP 009/2016), to Federal Goiano Institute for financial support and to Mr. Reinaldo for authorizing the data collection in his property.

\section{Author Contributions}

Ednaldo Cândido Rocha and Jhefferson Silva: concept and design of the study, performed collection of field data, and carried out the data analysis and wrote the paper.

Pablo Timóteo da Silva: contribution in the collection of field data.

Márcio da Silva Araújo and André Luis da Silva Castro: contribution in the data analysis, critical revision, and adding intellectual content.

\section{Conflicts of interest}

The authors declare no conflict of interest related to the publication of this manuscript.

\section{References}

AHUMADA, J.A., SILVA, C.E.F., GAJAPERSAD, K., HALLAM, C., HURTADO, J., MARTIN, E., MCWILLIAM, A., MUGERWA, B., O'BRIEN, T., ROVERO, F., SHEIL, D., SPIRONELLO, W.R., WINARNI, N. \& ANDELMAN, S.J. 2011. Community structure and diversity of tropical forest mammals: data from a global camera trap network. Phil. Trans. R. Soc. B. 366:2703-2711. 
ARITA, H.T., ROBINSON, J.G. \& REDFORD, K.H. 1990. Rarity in Neotropical Forest Mammals and its Ecological Correlates. Conserv. Biol. 4:181-192.

BECKER M. \& DALPONTE, J.C. 2013. Rastros de mamíferos silvestres brasileiros - um guia de campo. 3 ed. Technical Books Editora, Rio de Janeiro.

BOCCHIGLIERI, A., MENDONÇA, A.F. \& HENRIQUES, R.P.B. 2010. Composição e diversidade de mamíferos de médio e grande porte no Cerrado do Brasil central. Biota Neotrop. 10:169-176.

BRASIL. 2012. Novo Código Florestal brasileiro. Lei n ${ }^{\circ} 12.651$, de 25 de maio de 2012.

CARDILLO M. \& BROMHAM L. 2001. Body Size and Risk of Extinction in Australian Mammals. Conserv. Biol. 15:1435-1440.

CARDILLO, M., MACE, G.M., JONES, K.E., BIELBY, J., BININDAEMONDS, O.R.P., SECHREST, W., ORME, D.D.L. \& PURVIS, A. 2005. Multiple Causes of High Extinction Risk in Large Mammal Species. Science 309:1239-1241.

CARVALHO, F.M.V., DE MARCO JR, P. \& FERREIRA JUNIOR, L.G. 2009 The Cerrado into-pieces: Habitat fragmentation as a function of landscape use in the savannas of central Brazil. Biol. Conserv. 142:1392-1403.

CHIARELLO, A.G. 1999. Effects of fragmentation of the Atlantic forest on mammal communities in south-eastern Brazil. Biol. Conserv. 89:71-82.

COELHO, M., JUEN, L. \& MENDES-OLIVEIRA, A.C. 2014. The role of remnants of Amazon savana for the conservation of Neotropical mammal communities in eucalyptus plantations. Biodivers. Conserv. 23:3171-3184.

CULLEN JR., L., BODMER, R.E. \& VALLADARES-PÁDUA, C. 2000. Effects of hunting in habitat fragments of the Atlantic forests, Brazil. Biol. Conserv. 95:49-56.

DALE V.H., PEARSON S.M., OFFERMAN H.L. \& O’NEILL R.V. 1994. Relating Patterns of Land-Use Change to Faunal Biodiversity in the Central Amazon. Conserv. Biol. 8:1027-1036.

ESTRELA, D.C., D.C. SOUZA, J.M. SOUZA \& CASTRO, A.L.S. 2015 Medium and large-sized mammals in a Cerrado área of the state of Goiás, Brazil. Check List 11: article 1690.

FAHRIG, L. 2003. Effects of habitat fragmentation on biodiversity. Annu. Ver. Ecol. Syst. 34:487-515.

FAHRIG, L. 2013. Rethinking patch size and isolation effects: the habitat amount hypothesis. J. Biogeogr. 40:1649-1663.

GIBSON, L., LEE, T.M., KOH, L.P., BROOK, B.W., GARDNER, T.A., BARLOW, J., PERES, C.A., BRADSHAW, C.J.A., LAURANCE, W.F., LOVEJOY, T.E. \& SODHI, N.S. 2011. Primary forests are irreplaceable for sustaining tropical biodiversity. Nature 478:378-381.

GOTELLI, N.J. \& COLWELL, R.K. 2011. Estimating Species Richness. In: Biological Diversity: Frontiers in Measurement and Assessment (A.E. MAGURRAN \& B.J. McGILL, eds.). Oxford University Press, United Kingdom, p.39-54.

HANNIBAL W. 2014. Mammals of medium and large size from a fragmented seasonal forest landscape in Mato Grosso do Sul state, central-western Brazil. Check List 10:1430-1434.

HANSKI, I. \& OVASKAINEN, O. 2002. Extinction debt at extinction threshold Conserv. Biol. 16:666-673.

JACKSON, S.T. \& SAX, D.F. 2009. Balancing biodiversity in a changing environment: extinction debt, immigration credit and species turnover. Trends Ecol. Evol. 25:153-160.

KUUSSAARI, M., BOMMARCO, R., HEIKKINEN, R.K., HELM, A., KRAUSS, J., LINDBORG, R., OCKINGER, E., PARTEL, M., PINO, J., RODÀ, F., STEFANESCU, C., TEDER, T., ZOBEL, M. \& STEFFANDEWENTER, I. 2009. Extinction debt: a challenge for biodiversity conservation. Trends Ecol. Evol. 24:564-571.
LIRA, P.K., EWERS, R.M., BANKS-LEITE, C., PARDINI, R. \& METZGER, J.P. 2012. Evaluating the legacy of landscape history: extinction debt and species credit in bird and small mammal assemblages in the Brazilian Atlantic Forest. J. Appl. Ecol. 49:1325-1333.

LYRA-JORGE, M.C, CIOCHETI G. \& PIVELLO V.R. 2008. Carnivores mammals in a fragmented landscape in northeast of São Paulo state, Brazil. Biodivers. Conserv. 17:1573-1580.

MENDES, F.R., MIKICH, S.B., BIANCONI, G.V., PEDRO, W.A. 2005. Mamíferos do município de Fênix, Paraná, Brasil: etnozoologia e conservação. Rev. Bras. Zool., 22(4): 991-1002.

METZGER, J.P., MARTENSEN, A.C., DIXO, M., BERNACCI, L.C., RIBEIRO, M.C., TEIXEIRA, A.M.G. \& PARDINI, R. 2009. Time-lag in biological responses to landscape changes in a highly dynamic Atlantic forest region. Biol. Conserv. 142:1166-1177.

MICHALSKI, F. \& PERES, C.A. 2007. Disturbance-mediated mammal persistence and abundance-area relationships in Amazonian forest fragments. Conserv. Biol. 21:1626-1640.

MITTERMEIER, R.A., GIL, P.R., HOFFMAN, M., PILGRIM, J., BROOKS, T., MITTERMEIER, C.G., LAMOREUX, J. \& FONSECA, G.A.B. 2005. Hotspots Revisited: Earth's Biologically Richest and Most Endangered Terrestrial Ecoregions. CEMEX, Mexico City.

MMA - Ministério do Meio Ambiente. 2014. Lista Nacional Oficial de Espécies da Fauna Ameaçadas de Extinção. Portaria MMA n ${ }^{\circ} 444$, de 17 de dezembro de 2014.

NORRIS, D., PERES, C.A. \& HINCHSLIFFE, K. 2008. Terrestrial mammal responses to edges in Amazonian forest patches: a study based on track stations. Mammalia 72:15-23.

O'GRADY, J.J., REED D.H., BROOK B.W. \& FRANKHAM, R. 2004. What are the best correlates of predicted extinction risk? Biol. Conserv. 118:513-520.

OKSANEN, J., BLANCHET, F.G., FRIENDLY, M., KINDT, R., LEGENDRE, P., MINCHIN, D., MINCHIN, P.R., O'HARA, R.B., SIMPSON, G.L., SOLYMOS, P., STEVENS, M.H.H., SZOECS, E. \& WAGNER, H. 2018 vegan: Community Ecology Package. R package version 2.5-2. https:// CRAN.R-project.org/package $=$ vegan.

PAGLIA, A.P., FONSECA, G.A.B., RYLANDS, A.B., HERMANN, G., AGUIAR, L.M.S., CHIARELLO, A.G., LEITE, Y.L.R., COSTA, L.P., SICILIANO, S., KIERULFF, M.C.M., MENDES, S.L., TAVARES, V.C., MITTERMEIER, R.A. \& PATTON, J.L. 2012. Lista anotada dos mamíferos do Brasil. Occasional paper n. 6. Conservation International, Belo Horizonte.

PERES, C.A. 2000. Effects of subsistence hunting on vertebrate community structure in Amazonian Forests. Conserv. Biol. 14:240-253.

R CORE TEAM. 2018. R: A Language and Environment for Statistical Computing. Vienna, Austria, R Foundation for Statistical Computing.

ROCHA, E.C., BRITO, D., SILVA, P.M., SILVA, J., BERNARDO, P.V.S. \& JUEN, L. 2018. Effects of habitat fragmentation on the persistence of medium and large mammal species in the Brazilian Savanna of Goiás State. Biota Neotrop. 18:e20170483.

ROCHA, E.C., SOARES, K.L. \& PEREIRA, I.M. 2015. Medium-and largesized mammals in Mata Atlântica State Park, southeastern Goiás, Brazil. Check List 11:1-7.

SANO, E.E., ROSA, R., BRITO, J.L. \& FERREIRA JR, L.G. 2007. Mapeamento de cobertura vegetal do bioma Cerrado: estratégias e resultados. Documentos 190, Embrapa Cerrados, Planaltina.

SANTOS-FILHO, M., PERES, C.A., SILVA, D.J. \& SANAIOTTI, T.M. 2012. Habitat patch and matrix effects on small-mammal persistence in Amazonian Forest fragments. Biodivers. Conserv. 21:1127-1147.

SEMPER-PASCUAL, A., MACCHI, L., SABATINI, F.M., DECARRE, J., BAUMANN, M., BLENDINGER, R.G., GÓMEZ-VALENCIA, B., MASTRANGELO, M.E. E KUEMMERLE, T. 2018. Mapping extinction debt highlights conservation opportunities for birds and mammals in the South American Chaco. J. Appl. Ecol. 55:1-12. 
Rocha, E.C. et al.

SILVA, K.F.M. \& HENRIQUES, R.P.B. 2009. Ecologia de população e área de vida do tatu-mirim (Dasypus septemcinctus) em um Cerrado no Brasil Central. Edentata. 8:48-53.

STRASSBURG, B.B.N, BROOKS, T., FELTRAN-BARBIERI, R, IRIBARRE, A., CROUZEILLES, R., LOYOLA, R., LATAWIEC, A.E., OLIVEIRAFILHO, F.J.B., SCARAMUZZA, C.A.M., SCARANA, F.R., SOARESFILHO, B. \& BALMFORD, A. 2017. Moment of truth for the Cerrado hotspot. Nat. Ecol. Evol. 1: article 99.

TILMAN, D., MAY, R.M., LEHMAN, C.L. \& NOWAK, M.A. 1994. Habitat destruction and the extinction debt. Nature 371:65-66.

UEZU, A., METZGER, J. \& VIELLIARD, J. 2005. Effects of structural and functional connectivity and patch size on the abundance of seven Atlantic Forest bird species. Biol. Conserv. 123:507-519.
UMETSU, F., METZGER, J.P. \& PARDINI, R. 2008. Importance of estimating matrix quality for modeling species distribution in complex tropical landscapes: a test with Atlantic forest small mammals. Ecography 31:359370.

WOLFF, J.O., SCHAUBER, E.M. \& EDGE, W.D. 1997. Effects of habitat loss and fragmentation on the behavior and demography of Gray-tailed voles. Conserv. Biol. 11:945-956.

ZIMBRES, B., FURTADO, M.M., JÁCOMO, A.T.A., SILVEIRA, L., SOLLMANN, R., TÔRRES, N.M., MACHADO, R.B. \& MARINHOFILHO, J. 2013. The impact of habitat fragmentation on the ecology of Xenarthrans (Mammalia) in the Brazilian Cerrado. Landscape Ecol. 28:259-269.

Received: 03/10/2018

Revised: $16 / 05 / 2019$

Accepted: 20/05/2019

Published online: 27/06/2019 